\title{
PERAN KOMUNIKASI PPID PROPINSI BANTEN DALAM PELAYANAN INFORMASI PUBLIK
}

\author{
Hilman \\ Email: hilman@unis.ac.id \\ Program Studi Ilmu Administrasi Publik UNIS Syech Yusuf
}

\begin{abstract}
ABSTRAK
Keterbukaan informasi publik merupakan hak asasi manusia sesuai dengan Deklarasi universal hak asasi manusia (DUHAM), 10 Desember 1948 di Perserikatan Bangsa-bangsa (PBB). Sejalan dengan hal tersebut pemerintah Indonesia mengesahkan Undang-undang nomor 14 tahun 2008 tentang keterbukaan informasi publik. Dalam implementasi UU tersebut masih banyak ditemukan badan publik dalam hal ini peran Pejabat pengelola informasi dan Dokumentasi (PPID) belum maksimal, terbukti dengan meningkatnya permohonan sengketa informasi ke komisi informasi propinsi Banten. Oleh sebab itu perlu penguatan peran Komunikasi PPID Dalam Layanan Informasi Publik.
\end{abstract}

Kata kunci : Informasi Publik, Komunikasi, HAM

\begin{abstract}
Openness of public information is a human right in accordance with the Universal Declaration of Human Rights (UDHR) on December 10, 1948 at the United Nations (UN), according to this the Indonesian government issued Law number 14 of 2008 concerning disclosure of public information. In the implementation of this law, there are still many public institutions found, in this case the role of the Information Management and Documentation Officer (PPID) has not been maximized, as evidenced by the support of information delegation about the Banten provincial information commission. Therefore it is necessary to conflict the role of PPID Communication in public information services.
\end{abstract}

Keywords: Public Information, Communication, Human Right

\section{Pendahuluan}

Informasi merupakan kebutuhan bagi setiap warga negara untuk mengembangkan diri dan lingkungan sosialnya serta menjadi kewajiban bagi negara untuk melindunginya. Di negaranegara demokrasi seperti halnya Indonesia, informasi merupakan oksigen atau nafas bagi setiap komponen bangsa. Tanpa informasi yang memadai, mustahil bagi publik dapat mengembangkan partisipasi politik, dimana Partisipasi politik merupakan salah-satu indikator kemajuan demokrasi suatu negara.

Keterbukaan informasi menjadi sarana optimalisasi pengawasan masyarakat terhadap penyelenggaraan negara, yaitu penyelenggaraan negara yang bersih dari korupsi, kolusi, dan nepotisme. Diterbitkannya UU nomor 14 tahun 2008, telah dan akan menjadi salah-satu instrumen untuk mewujudkan negara demokrasi yang transfaran. Kebebasan informasi merupakan hak asasi manusia yang diakui oleh hukum internasional, maka pemerintah Indonesia turut serta mendorong keterbukaan informasi sampai pada pemerintahan Desa.

Peran komunikasi formal dan informal menjadi tanggung jawab pejabat pengelola informasi dan dokumentasi (PPID) di propinsi Banten. Komunikasi yang dimaksud adalah tentang sejauhmana layananan yang mengacu pada standar layanan informasi Publik (SLIP). Pada tataran implementasi terdapat lemahnya 
Komunikasi formal dan informal PPID, terbukti meningkatnya penyelesaian sengketa informasi di komisi informasi propinsi Banten sejak tahun 2011-2019 sebagai berikut:

\begin{tabular}{|c|c|}
\hline Tahun & $\begin{array}{c}\text { Jumlah Permohonan } \\
\text { Sengketa Informasi }\end{array}$ \\
\hline 2011 & 28 Register \\
\hline 2012 & 117 Register \\
\hline 2013 & 450 Register \\
\hline 2014 & 257 Register \\
\hline 2015 & 387 Register \\
\hline 2016 & 89 Register \\
\hline 2017 & 392 Register \\
\hline 2018 & 85 Register \\
\hline 2019 & 57 Register \\
\hline
\end{tabular}

Tabel 1.1 Data jumlah permohonan sengketa informasi di propinsi Banten

Peran Komunikasi PPID utama/pembantu di Pemerintah Propinsi Banten akan mempermudah dalam menjawab permasalahan yaitu; Pertama, Bagaimana peran komunikasi yang efektif bagi Pejabat Pengelola Informasi dan Dokumentasi (PPID) di pemerintah propinsi Banten?, kedua, bagaimana meningkatkan layanan informasi publik?, ketiga, Bagaimana strategi mengurangi jumlah sengketa informasi publik.

Sengketa informasi publik terjadi akibat tidak terpenuhinya permohonan informasi yang diajukan oleh pemohon. Pada kontek tidak terpenuhinya pelayanan informasi terdapat peran strategis aparatur negara/ publik yaitu pejabat pengelola informasi dan dokumentasi. Peran strategis tersebut perlu adanya dukungan dkebijakan berupa regulasi, sumberdaya manusia dan anggaran. Dukunga pemerintah propinsi banten terhadap terhadap penempatan sumberdaya manusia dan anggaran belum maksimal saat ini. Akibatnya peran komunikasi PPID sebagai unjung tombak pelayanan informasi terhambat.

\section{Metode Penelitian}

Penelitian ini merupakan penelitian deskriftif-analisis. Penelitian dimulai dengan menelaah data sekunder ( ketentuan perundang-undangan yang berkaitan dengan keterbukaan informassi publik di propinsi Banten) diikuti dengan penelaahan data primer dari lapangan dan dianalisis dengan perundangan-undangan serta teori yang relevan. Materi yang menjadi fokus dalam penelitian ini adalah terkait dengan peran komunikasi pejabat pengelola informasi dan dokumentasi (PPID) di propinsi Banten, sebagai basis datanya primer yaitu jumlah permohonan sengketa informasi publik di propinsi Banten sejak 2011-2019.

\section{Pembahasan}

\section{A. Komunikasi}

Komunikasis berasal dari bahasa Latin communico artinya membagi, dan communis berarti membangun kebersamaan antara dua orang atau lebih(Cangara, 2009: 13). Dalam Effendy (2004:9) dikatakan bahwa kegiatan komunikasi tidak hanya bersifat informatif yang hanya mampu memberikan pengetahuan dan pengertian kepada orang lain, juga bersifat persuasif, yakni supaya orang lain bersedia menerima paham atau keyakinan untuk perbuatan dan kegiatan lainnya.

Halliday (1994) dalam komunikasi mempergunakan istilah fungsi, dalam hasil penelitiannya ada tujuh fungsi komunikasi yaitu : Instrumental, regulasi, represintasional, interaksional, personal, heuristik, dan imajinatif. Maka tujuh fungsi komunikasi terdapat relevansi dengan peran Pejabat Pengelola Informasi dan Dokumentasi (PPID) di propinsi Banten.

Berbicara pada hakikatnya adalah proses komunikasi secara lisan antara pembicara dan lawan bicara. Menurut Tarigan (1990:15), berbicara adalah kemampuan mengucapkan bunyi-bunyi artikulasi atau kata-kata untuk 
mengekspresikan, menyatakan, serta menyampaikan pikiran, gagasan dan perasaan. Maka sesungguhnya peran PPID adalah berbicara untuk menyampaikan tentang informasi berkala, serta merta dan informasi setiap saat yang terdapat pada pasal 9,10, dan 11 undang-undang nomor 14 tahun 2008.

Dalam proses komunikasi terjadi pemindahan pesan dari komunikator kepada komunikan. Simbol tersebut memerlukan saluran sehingga dapat dipindahkan ke komunikan. Saluran untuk memindahkan melalui media udara. Bahasa lisan adalah alat komunikasi berupa simbol yang dihasilkan oleh alat ucap manusia.

Meningkat atau menurunnya jumlah sengketa informasi akan tergantung pada peran komunikasi PPID terhadap pemohon informasi. Karena sejalan dengan hal tersebut akan mengurangi jumlah sengketa informasi yang diajukan pemohon informasi ke komisi informasi. Maka komunikasi dengan pendekatan regulasi dan fungsi komunikasi personal menjadi lebih dominan dilakukan oleh PPID di propinsi Banten.

\section{B. Pelayanan Publik}

Pelayanan publik merupakan tuntutan dari masyarakat terhadap negara, tuntutan yang menyangkut kepentingan publik. agar mereka mendapatkan hak dan perlakuan yang layak dari negara. Pelayanan publik diberikan oleh negara melalui birokrasi harus berorientasi pada kepentingan publik. Hal tersebut seiring dengan pendapat Dwiyanto (2006:57) memahami kualitas pelayanan publik, yakni : pertama adminitrasi klasik dan administrasi klien; kedua manajemen publik dan kepuasan pelanggan; ketiga pelayanan publik baru dan kualitas pelayanan bagi warga negara.

Terkait dengan pelayanan publik, Christian Gronroos dalam Alma (2007: 216) mengemukakan bahwa, kualitas jasa dari sudut penilaian pelanggan (masyarakat) dibedakan atas tiga dimensi

1) Outcome dimension, yaitu berkaitan apa yang diterima konsumen atau publik;

2) Process related dimension, yaitu berkaitan dengan cara jasa disampaikan atau disajikan;

3) Corporate image, yaitu berkaitan dengan citra perusahaan/badan publik di mata konsumen dimensi ini sama dengan kredibilitas;

Pelayanan publik merupakan salah satu aspek krusial dan menjadi bagian penting dalam mendukung penguatan pelaksanaan manajemen publik. Dengan demikian tingkat keberhasila manajemen publik yang dselenggarakan oleh pemerintah akan tercermin salahsatunya dari kualitas pe;ayanan publik. Dalam kontek inilah penyedia peleayanan publik dituntut untuk menghadirkan sebuah produk yang tidak saja dapat memuaskan masyarakat, tetapi juga mampu memberikan pelayanan publik secara mengesankan.

Standar pelayanan publik yang harus di terapkan dalam setiap proses pelayanan, menurut Mahmudi (2007:220-221) sekurang-kurangnya meliputi enam hal yaitu : Prosedur pelayanan, waktu penyelsaian, biaya pelayanan, produk pelayanan, sarana dan prasarana, serta petugas pemberi pelayanan. Pandangan yang lebih esensial pelayanan publik terdapat pada undang-undang nomor 25 tahun 2009 tentang pelayanan publik pasal 21.

Maka dengan pendekatan teori tersebut, pelayanan informasi publik menjadi dominan diberikan oleh negara terhadap masyarakat. Karena pada akhirnya publik akan menuntut pelayanan yang terbaik dari negara. Sehingga pintu masuk pelayanan informasi publik akan terletak pada sejauhmana peran PPID pemerintah propinsi Banten 
mengimplementasikan berbagai regulasi yang ada saat ini.

\section{Layanan Informasi Publik}

Pada UUD 45 pasal $28 \mathrm{~F}$ di sebutkan " setiap orang berhak untuk berkomunikasi dan memperoleh informasi untuk mengembangkan pribadi dan lingkungan sosialnya, serta berhak untuk mencari, memperoleh, memiliki, menyimpan, mengolah dan menyampaikan informasi dengan menggunakan segala jenis saluran yang tersedia”. Pasal 28 $\mathrm{F}$ ini mengindikasikan bahwa negara hadir dan menjamin dalam pemenuhan hak asasi manusia (HAM) bagi setiap warganya.

Sementara pada ayat 3 disebutkan "Badan Publik adalah lembaga eksekutif, legislatif, yudikatif dan badan lain yang fungsi dan tugas pokoknya berkaitan dengan penyelenggaraan negara, yang sebagian atau seluruh dananya bersumber dari APBN/APBD atau organisasi nonpemerintah sepanjang sebagaian atau seluruh dananya bersumber dari APBN/APBD, sumbangan masyarakat, dan/atau luar negeri.

Peraturan komisi informasi tentang Standar layanan informasi publik, terdapat kewajiban dari badan publik untuk membuat laporan layanan informasi pada setiap tahunnya. Laporan tersebut harus disampaikan kepada komisi informasi paling lambat tiga bulan setelah pelaksanaan tahun anggaran. Artinya maksimal setiap bulan Maret, maka badan publik harus sudah meyampaikan laporan layanan informasi tersebut.

Ditinjau dalam kontek regulasi, maka sesungguhnya peran pemerintah lebih besar untuk menjadi pendorong keterbukaan informasi publik di propinsi Banten khusunya. Karena hakikatnya Badan publik harus memenuhi kebutuhan hak akses warga negara, oleh sebab itu peningkatan sarana dan prasarana menjadi kunci kepuasan publik.

$\begin{array}{cr}\text { Pendekatan dengan } & \begin{array}{r}\text { Penerapan } \\ \text { peraturan }\end{array} \text { daerah }\end{array}$

mengimplementasikan keterbukaan informasi publik telah dilakukan oleh pemerintah propinsi Banten melalui Keputusan Gubernur nomor : 499.05/kep.216-Huk/2013 tentang Perubahan keputusan Gubernur Banten nomor : 499.05/kep.673-Huk/2011 tentang Pejabat Pengelola Informasi dan Dokumentasi dilingkungan Propinsi Banten, dalam keputusan Gubernur tersebut telah menempatkan susunan keanggotaan Pejabat Pengelola Informasi dan Dokumentasi (PPID) dilingkungan propinsi Banten yaitu dimana Kepala Biro Humas dan protokoler sekretariat daerah propinsi Banten sebagai Pejabat Pengelola Informasi dan Dokumentasi (PPID) utama dan sekertaris disemua Satuan kerja perangka daerah (SKPD) di tempatkan sebagai Pejabat Pengelola Informasi dan Dokumentasi (PPID) Pembantu dengan jumlah 43 yang tersebar disemua satuan kerja Perangkat daerah (SKPD). Dalam kontek ini sejak tahun 2016 telah terbit peraturan daerah nomor 8 tahun 2016 tentang pembentukan dan susunan perangkat daerah propinsi Banten. Maka susunan keanggotaan khususnya Pejabat Pengelola Informasi dan Dokumentasi (PPID) utama berubah yaitu menjadi Dinas Komunikasi informasi persandian dan statistik. Pada tahun 2017 dikeluarkan Keputusan Gubernur nomor 489.1/kep.113.huk/2017 tentang penetapan pejabat pengelola informasi dan dokumentasi di lingkungan pemerintah propinsi Banten yang berlaku sampai dengan saat ini.

\section{Pejabat Pengelola Informasi dan Dokumentasi}

Pejabat Pengelola informasi dan dokumentasi (PPID) adalah pejabat yang bertanggung jawab dibidang 
Penyimpanan, pendokumentasian, penyediaan, dan/atau pelayanan informasi di badan publik. Kemudian dalam Peraturan Menteri dalam negeri Republik Indoensia nomor: 3 tahun 2017 tentang pedoman pengeloaan pelayanan informasi dan dokumentasi dilingkungan Kementerian dalam negeri dan pemerintah daerah. pada pasal 1 ayat 10 disebutkan bahwa Pejabat Pengelola informasi dan dokumentasi(PPID) adalah pejabat yang bertanggung jawab dalam Pengumpulan, pendokumentasian, penyimpanan, pemeliharaan, penyediaan, distribusi, dan pelayanan informasi dan dokumentasi dilingkungan Kemendagri dan pemerintah daerah, yang terdiri dari Pejabat Pengelola informasi dan dokumentasi (PPID) utama/pembantu. Kemudian yang dimaksud dengan atasan PPID adalah pejabat yang merupakan atasan Pejabat Pengelola informasi dan dokumentasi (PPID) utama.

Di bawah ini digambarkan peran PPID dalam memberikan layanan permohonan informasi sebagai berikut : informatika statistik dan persandian, hal ini dimaksudkan untuk menghindari adanya keberatan terhadap atasan PPID.

Ada konsekuensi hukum apabila permohonan informasi ini tidak diberikan kepada pemohon informasi. Konsekuensi tersebut berupa ada hak dari pemohon untuk menyapaikan permohonan penyelesaikan sengketa informasi. Skema permohona sengketa tersebut dapat digambarkan seperti di bawah ini :



Penyelesaian sengketa informasi merupakan jalan terakhir bagi para pihak untuk bisa mengkomunikasikan tentang masing-masing kepentingannya. Maka pada tahap ini para pihak harus mampu menyakinkan bahwa informasi yang di

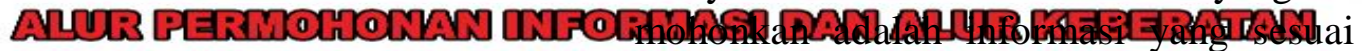

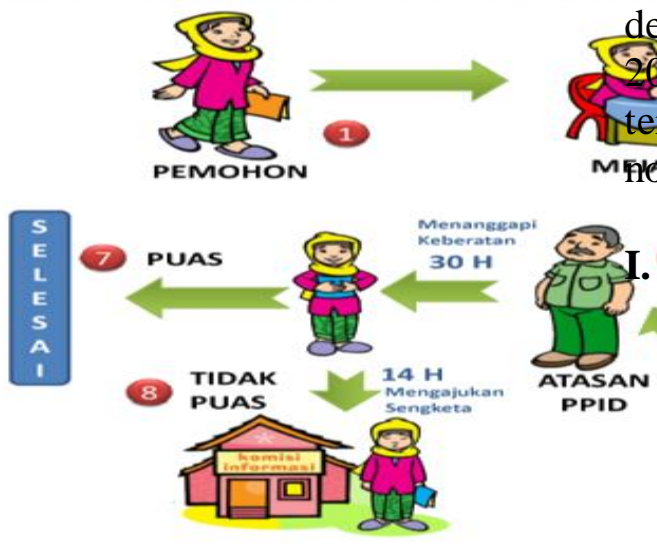

Dalam gambar alur permohonan informasi publik, terdapat peran PPID yang hanya memiliki batas waktu 10 hari dan 7 hari kerja untuk menjawab permohonan. Dilihat dalam kontek ini maka peran komunikasi formal dan informal kepada pemohon informasi memegang peran penting. Hal ini harus dilakukan oleh PPID pembantu di SKPD dan PPID utama di Dinas Komunikasi dengan undang-undang nomor 14 tahun

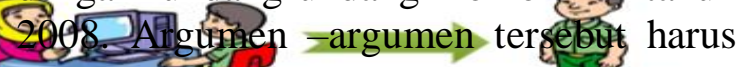
tersampaikan dalam sidang Ladjudikasi mpronlitigasio \&1 komisi informasi. PPID

\section{SIMPULAN DANSARAN}

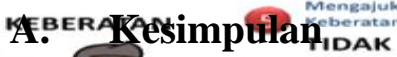

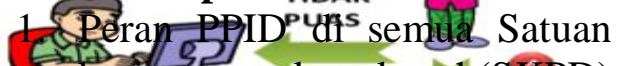

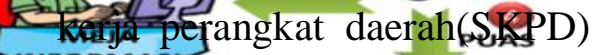
Eqafam komunikasi formal dan informal terhadap pemohon informasi publik menjadi salah satu faktor penentu dalam memberikan layanan informasi publik di propinsi Banten. Pendekatan regulasi sebagai sarana formal harus dijadikan pedoman bagi pemohon informasi maupun bagi badan publik, hal ini penting dilakukan sebagai bentuk 
adanya kepastian hukum bagi para pihak.

2. Kebijakan pelayanan informasi dilakukan oleh pemerintah propinsi Banten saat ini belum optimal dalam tataran implementasi, hal ini bisa dilihat dari masih tingginya jumlah permohonan informasi publik oleh pemohon informasi kepada Pejabat pengelola informasi dan dokumentasi (PPID) yang belum terlayani.

3. Sarana dan prasarana penunjang kinerja Pejabat pengelola informasi dan dokumentasi(PPID) belum maksimal, termasuk dukungan anggaran dan sumberdaya manusianya. Regulasi yang ideal dan mengikat kepada Pejabat pengelola informasi dan dokumentasi (PPID) pembantu di setiap satuan kerja perangkat daerah (SKPD) belum dijalankan dengan baik.

4. Pemeringkatan Badan Publik yang menjadi program rutin komisi informasi dilaksanakan setiap tahun dengan berpedoman pada Peraturan komisi informasi (PERKI) nomor 5 tahun 2016 tentang Metode dan Teknik Evaluasi keterbukaan informasi badan Publik, Pemeringkatan Badan Publik juga pada pada Peraturan komisi informasi (PERKI) nomor 1 tahun 2010 tentang standar layanan Informasi publik (SLIP), pemeringkatan tersebut dimaksudkan dalam rangka memastikan badan publik untuk benar-benar menjalankan UU KIP.

\section{B. Saran}

Pendekatan untuk menjadikan Banten sebagai propinsi yang informatif pada tahun 2020, perlu di perkuat pada tiga aspek yaitu: peningkatan sumber daya manusia (SDM), regulasi yang memadadi, dukungan anggaran, dan peningkatan pelatihan Komunikasi yang berkala terhadap pejabat pengelola informasi dan dokumentasi(PPID) semua SKPD di propinsi Banten.

\section{DAFTAR PUSTAKA}

Cangara, Hafid, 2009. Pengantar Ilmu

Komunikasi. Jakarta: PT. Raja Grafindo

Persada

Efendy, Omong Uchjana, 2004. Dinamika

Komunikasi. Bandung: PT. Remaja Rosda

Karya

Dwiyanto, Agus, 2010, Reformasi

Birokrasi Publik di Indonesia, Yogyakarta

: Gajahmada university press

Gronroos, Christian, 1990. Servis

management and marketing: managing the moments of truth in servis competition,

Singapore: Maxwell Macmillian

M.A.K Halliday dan Ruqaya hasan.

Bahasa konteks dan Teks. Terjemahaan

oleh Asruddin Barori Tou. Yogyakarta:

Gajahmada Press. 1994

Mahmudi, 2007, Manajemen Kinerja

Sektor Publik, Yogyakarta : UPP STIM

YKPN

Undang-undang nomor: 14 tahun 2008 tentang Keterbukaan informasi Publik

Undang-undang nomor: 23 tahun 2000 tentang Pembentukan Propinsi Banten

Undang-undang nomr 25 tahun 2009 tentang pelayanan publik

PERKI nomor: 1 tahun 2010 tentang Standar Layanan informasi Publik 
PERKI nomor: 5 tahun 2016 tentang Metode dan teknik evaluasi keterbukaan informasi badan publik.

PERMENDAGRI nomor: 3 tahun 2017 tentang Pedoman pengelolaan pelayanan informasi dan dokumentasi dilingkungan Kementerian Dalam negeri dan Pemerintah daerah
Keputusan Gubernur nomor : 499.05/kep.216-Huk/2013 tentang Perubahan keputusan Gubernur Banten nomor : 499.05/kep.673Huk/2011 tentang Pejabat Pengelola Informasi dan Dokumentasi dilingkungan Propinsi Banten 